\title{
Chromosome mapping of repetitive sequences in Anostomidae species: implications for genomic and sex chromosome evolution
}

\author{
Edson Lourenço da Silva, Rafael Splendore de Borba and Patrícia Pasquali Parise-Maltempi
}

\begin{abstract}
Background: Members of the Anostomidae family provide an interesting model system for the study of the influence of repetitive elements on genome composition, mainly because they possess numerous heterochromatic segments and a peculiar system of female heterogamety that is restricted to a few species of the Leporinus genus. The aim of this study was to isolate and identify important new repetitive DNA elements in Anostomidae through restriction enzyme digestion, followed by cloning, characterisation and chromosome mapping of this fragment. To identify repetitive elements in other Leporinus species and expand on studies of repetitive elements in Anostomidae, hybridisation experiments were also performed using previously described probes of LeSpel repetitive elements.

Results: The 628-base pair (bp) LeSpell fragment was hybridised to metaphase cells of $L$. elongatus individuals as well as those of L. macrocephalus, L. obtusidens, L. striatus, L. lacustris, L. friderici, Schizodon borellii and S. isognathus. In L. elongatus, both male and female cells contained small clusters of LeSpell repetitive elements dispersed on all of the chromosomes, with enrichment near most of the terminal portions of the chromosomes. In the female sex chromosomes of $L$. elongatus $\left(Z_{2}, Z_{2} W_{1} W_{2}\right)$, however, this repeated element was absent. In the remaining species, a dispersed pattern of hybridisation was observed on all chromosomes irrespective of whether or not they were sex chromosomes. The repetitive element LeSpel produced positive hybridisations signals only in L. elongatus, $L$. macrocephalus and L. obtusidens, i.e., species with differentiated sex chromosomes. In the remaining species, the LeSpel element did not produce hybridisation signals.

Conclusions: Results are discussed in terms of the effects of repetitive sequences on the differentiation of the Anostomidae genome, especially with respect to sex chromosome evolution. LeSpell showed hybridisation patterns typical of Long Interspersed Elements (LINEs). The differential distribution of this element may be linked to sex chromosome differentiation in L. elongatus species. The relationship between sex chromosome specificity and the LeSpel element is confirmed in the species L. elongatus, L. macrocephalus and L. obtusidens.
\end{abstract}

Keywords: Chromosomes, FISH, Heterochromatin, Neotropical fish, Sex chromosomes

\section{Background}

Studies of Neotropical fishes indicate that only a few numbers contain heteromorphic sex chromosomes [1]. However, simple and multiple systems of heterogamety have been identified in various groups of fish [2-4]. An interesting feature in the distribution of these systems is that for both male and female heterogamety, multiple and simple systems, as well the sporadic occurrence of

\footnotetext{
* Correspondence: parise@rc.unesp.br

Departamento de Biologia, Laboratório de Citogenética, Instituto de Biociências, Universidade Estadual Paulista "Julio de Mesquita Filho" - UNESP, Av. 24A, 1515, Rio Claro, SP CEP 13506-900, Brazil
}

heterogamety, can be found in related species and in different populations of the same species [2]. This diversity in the sex chromosome structure of fishes has been attributed in part to the dynamics of repetitive DNA present on the chromosomes [5-8].

In the eukaryotic genome, there are two classes of repetitive elements: sequences organised in tandem repeats such as satellites, minisatellites and microsatellites, and sequences dispersed in the genome as transposons and retrotransposons [9]. In eukaryotes, proteincoding sequences can constitute as little as $2-10 \%$ of the genome, with the remainder of the genome comprising

\section{Biomed Central}


introns, intragenic regions, regulatory DNA sequences and a variety of repetitive sequences $[10,11]$.

Members of the Anostomidae family, particularly the Leporinus genus, are an interesting model system for the study of repetitive elements that influence the composition of the genome. This genus is particularly attractive due to the presence of the peculiar sex chromosome system $\mathrm{ZZ}$ and $\mathrm{ZW}$ in some species. Some studies focusing on the isolation, characterisation and correlation of these repetitive elements with the presence and evolution of sex chromosomes have highlighted the great potential of studying these elements in these Anostomidae species [5,12-15].

The repetitive element LeSpeI, which was previously isolated from the species L. elongatus [5], shows a sexspecific pattern that highlights the relationship of this element to the process of sex chromosome differentiation in $L$. elongatus, as well the congeneric species $L$. macrocephalus and L. obtusidens [13]. Besides this sequence was not found in L. friderici (which lack differentiated sex chromosomes), reinforcing the notion that this element is linked to sex chromosome differentiation [13]. In addition, LeSmaI, another satellite DNA element isolated from L. elongatus, displayed the species-specific characteristic of localisation near the nucleolar organiser region in both males and females [14]. Interestingly, at least in L. elongatus, the nucleolar organiser regionbearing chromosomes may comprise a probable multiple sex chromosome system $\left(\mathrm{Z}_{2}\right.$ and $\left.\mathrm{W}_{2}\right)$.

Indeed, the participation of repetitive sequences in sex chromosome differentiation in Anostomidae is certain; however, the role of these sequences in this complex process is still unknown. In this study, we identified a new repetitive element from $L$. elongatus, LeSpeII. In addition, we investigated the localisation of the repetitive element LeSpeI in four Anostomidae species not studied previously to help elucidate the association of repetitive sequences in the diversification of the Anostomidae genome, particularly sex chromosome differentiation.

\section{Results}

\section{Chromosome number of anostomids and analysis of a} repetitive sequence

Cytogenetic analysis of various anostomids revealed a diploid chromosome number of 54, with both metacentric- and submetacentric-type chromosomes. The cloned fragments (628 bp) had high AT content (64.9\%) and showed perfect sequence alignment among the clones (Figure 1). A BLASTN search did not reveal significant similarities between this sequence and previously identified sequences. This newly identified sequence was designated LeSpeII.

\section{Genomic hybridisation of LeSpell}

The LeSpeII probe was labelled and hybridised to the digested genomic DNA of male and female L. elongatus, individuals using Southern blot analysis. The probe hybridised to many different restriction fragments of various sizes, rather than to one band, which indicates that LeSpeII is predominately dispersed, not tandemly arrayed (Figure 2).

\section{Chromosomal distribution of repetitive DNA}

The chromosomal distribution of the LeSpeII element was determined by Fluorescence in situ hybridisation (FISH) analysis using metaphase spreads of male and female L. elongatus individuals. Small clusters of signals were found to be dispersed throughout all of the chromosomes, with enrichment near most terminal portions of the chromosomes (Figure 3a). In the sex chromosomes of

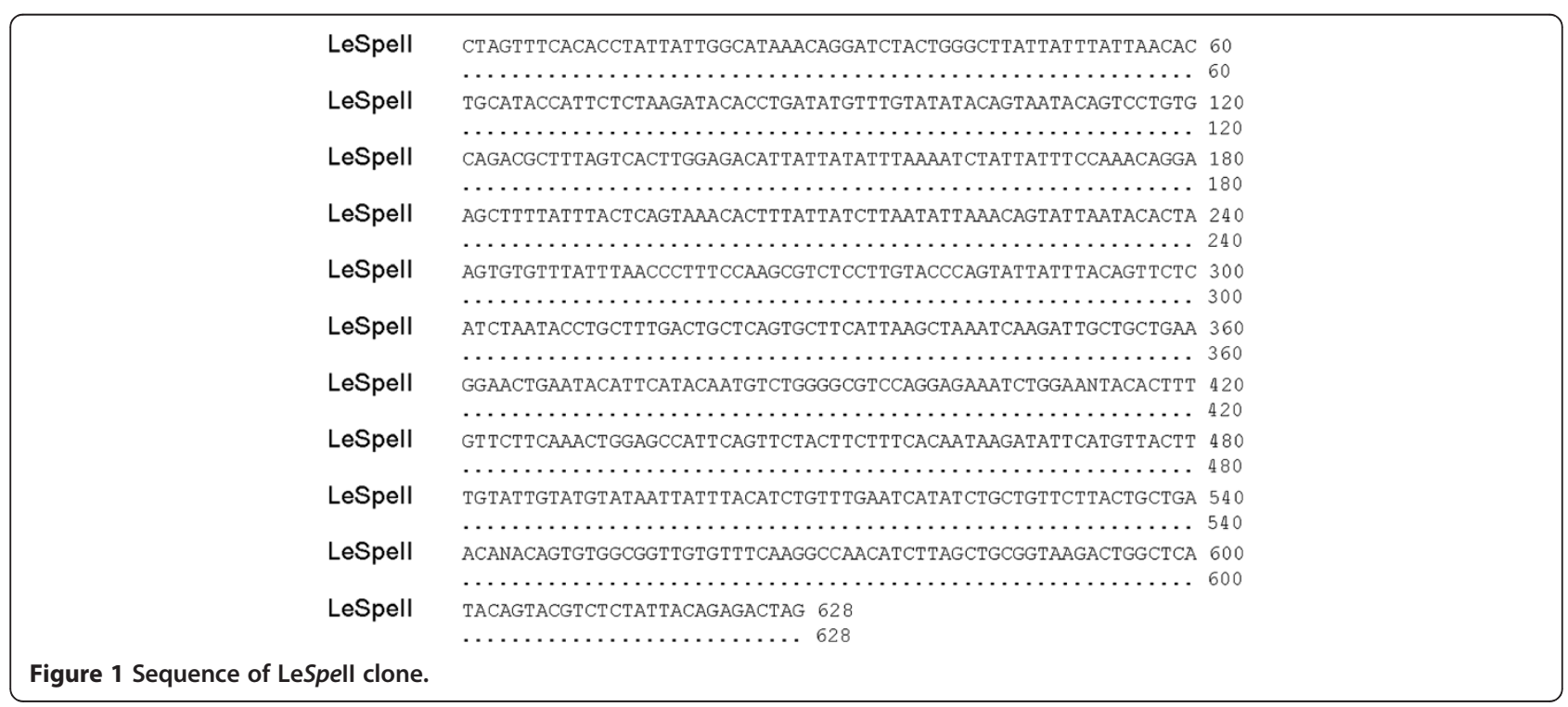




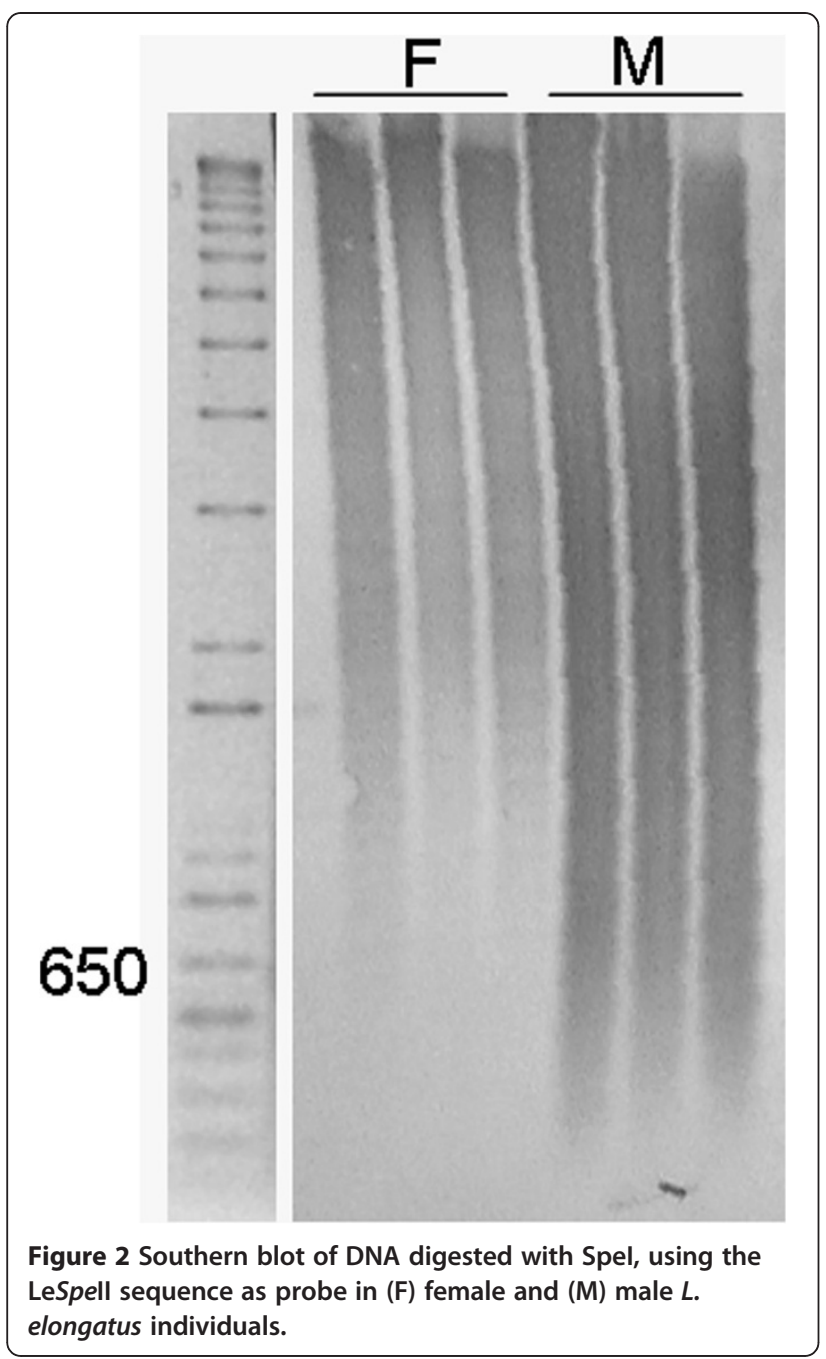

L. elongatus, however, this repeated element was absent, even when low stringency wash conditions were employed (Figure 3a). In the remaining species, i.e., $L$. macrocephalus, $L$. obtusidens $L$. friderici, $L$. striatus, $L$. lacustris, Schizodon borellii and S. isognathus, a dispersed signal pattern was observed in all chromosomes, with no indication of sex specificity (Figure $3 \mathrm{~b}-\mathrm{h}$ ).

The distribution patterns of the LeSpeI element in $L$. elongatus, L. macrocephalus, L. obtusidens and L. friderici were similar to those described by Parise-Maltempi et al. [4] and Marreta et al. [16], who detected positive signals on the $\mathrm{Z}_{2} \mathrm{Z}_{2}$ chromosomes of males and the $\mathrm{W}_{1} \mathrm{Z}_{2}$ and $\mathrm{W}_{2}$ chromosomes of female individuals of $L$. elongatus (Figure 4a); while in L. macrocephalus and $L$. obtusidens females, positive signals were detected on the long arm of the W chromosome (Figure 4b, c). L. friderici, L. striatus, L. lacustris, Schizodon borellii and S. isognathus did not show LeSpeI hybridisations signals even under low stringency conditions (Figure $4 \mathrm{~d}-\mathrm{h}$ ).

\section{Discussion}

Several repetitive elements have previously been isolated from several Leporinus species. These elements exhibited wide diversity with respect to chromosomal location and distribution [5,12-15]. The organisational patterns of these repetitive sequences demonstrate the dynamics of the fish genome, despite the apparent chromosomal stability that has been observed in the Anostomidae family since the first cytogenetic studies were performed in the 1980s (E.L. Silva, personal communication).

The predominantly dispersed distribution pattern of the LeSpeII element revealed by Southern blot analysis was consistent with the genomic organisation of most, if not all, previously analysed LINEs. Moreover, this characteristic distribution pattern differed from that of other previously described repetitive elements of the anostomids. LINE elements comprise a class of Non-LTR retrotransposons, which are an important group of repetitive DNA elements widely studied in many organisms (see [6]). The accumulation of LeSpeII near the telomeres of almost all chromosomes of the analysed anostomids was similar to the distribution pattern observed for the LINE CiLINE2 [17]. Higashiyama et al. [18] suggested that because these elements display terminal distribution, they may play a role in the stabilisation of the chromosomes on which they reside, in some circumstances, or they might form a structural cap to protect the terminal portions of the chromosomes. In fact, the sex chromosome system of $L$. elongatus is considered to still be undergoing evolution [5]; thus the absence of LeSpeII favours an environment of instability, which is required for ongoing evolution.

In some groups of vertebrates, dispersed elements are arranged in clusters and blocks that can easily be visualised on chromosomes $[19,20]$, but in some fish species, these elements have a widely scattered distribution pattern on all of the chromosomes [19,21]. These sequences have been associated with the evolution of the genome size of the host organism [22]. Indeed, these sequences elicit alterations in gene function through the process of insertion, inducing chromosomal rearrangements and the production of coding and non-coding material, thereby allowing new genes or new regulatory sequences to emerge [23]. These elements are therefore potentially associated with speciation events [24].

A series of repetitive DNA elements isolated from the Leporinus genus have been used as probes in chromosome mapping. All of these DNA families presented different distribution patterns, adding unique features to some species, including sex-specific sequences and species-specific repeated elements. Nakayama et al. [12] described two different sequences, including one found in both $\mathrm{Z}$ and $\mathrm{W}$ chromosomes and the other representing a second family specific to the $\mathrm{W}$ chromosome. 


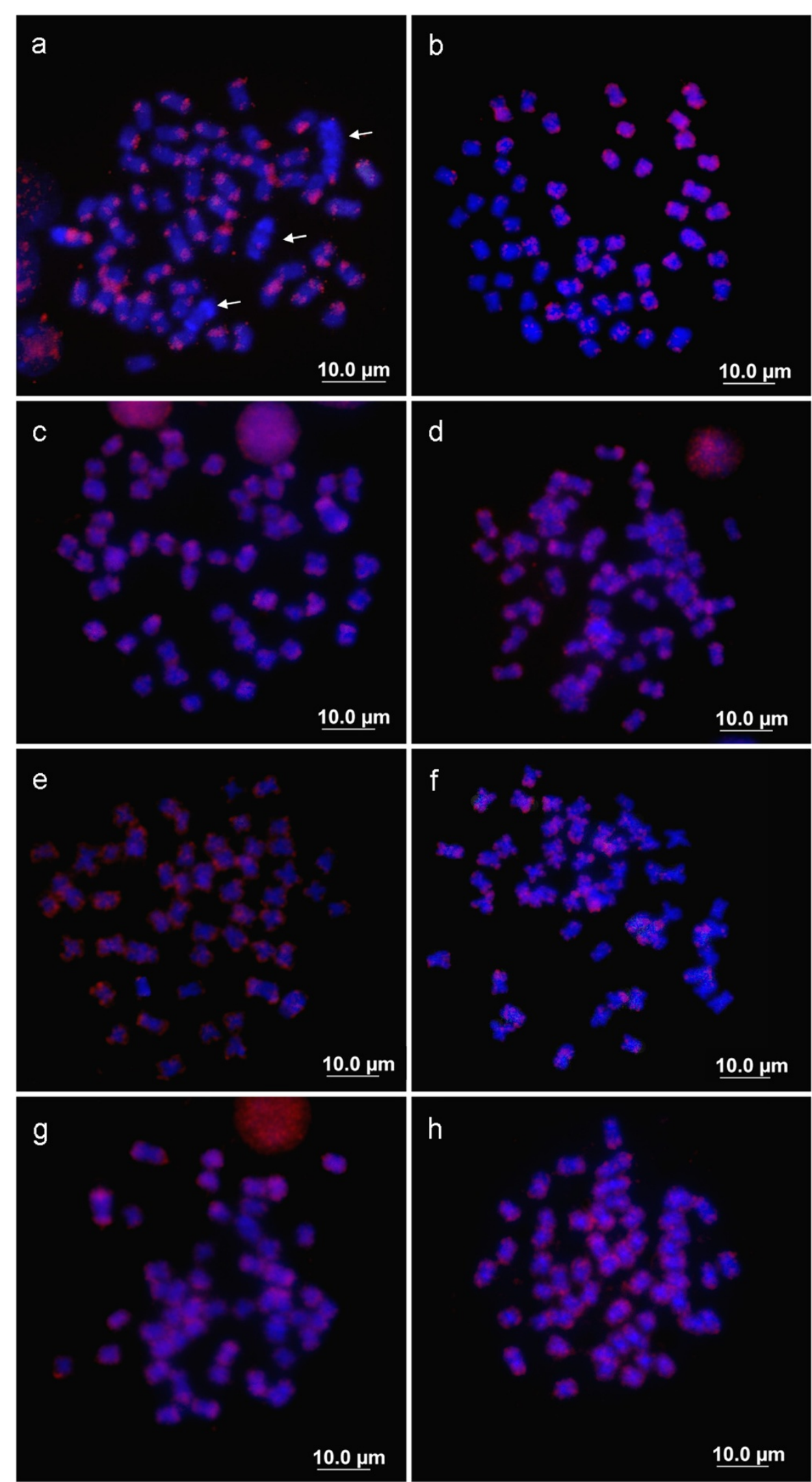

Figure $\mathbf{3}$ (See legend on next page.) 
(See figure on previous page.)

Figure 3 Mitotic metaphase chromosomes of Anostomidae representatives hybridised with the LeSpell repetitive element. a- Leporinus elongatus (female); b- L. macrocephalus (male); c- L. obtusidens (female); $\mathbf{d}$ - L. friderici (female); e- L. striatus (female); f- L. lacustris (female); g- Schizodon borellii (female); h- S. isognathus. Arrows indicate sex chromosomes in L. elongatus.

LeSpeI repetitive DNA was described as a sex-specific dispersed repetitive element with distinct distribution patterns on two exclusive female chromosomes, named $\mathrm{W}_{1}$ and $\mathrm{W}_{2}$ by Parise-Maltempi et al. [5]. This sequence was used to probe chromosomal preparations from L. macrocephalus, L. obtusidens and L. friderici, which displayed positive signals only on the W chromosomes of $L$. macrocephalus and L. obtusidens [13]. Here, we examined the distribution patterns of LeSpeI in these species, as well in L. striatus, L. lacustris, Schizodon borellii and S. isognathus, which are all from different hydrographic basins, and we corroborated the sex chromosome specificities of this sequence. Besides the repetitive sequences associated with differentiated sex chromosomes, also a satellite DNA, LeSmaI, has also been isolated from L. elongatus [14]. This satellite DNA, which is linked to nucleolar organiser regions (classified as chromosomes $\mathrm{Z}_{2}$ and $\mathrm{W}_{2}$ by Parise-Maltempi et al. [5]), is exclusively found in L. elongatus, in both male and female individuals.

The simple sex chromosome system originated from a pair of autosomes that, for some reason, stopped recombining and gradually diverged from each other [25]. This process of sex-chromosome evolution has attracted considerable interest over the years, and an important question has been what the evolutionary forces are that act to make a pair of autosomes cease recombining in one sex, eventually leading to the formation of two discrete chromosome types [26].

A series of heterochromatin acquisitions may have driven the morphological differentiation of simple sex chromosomes found in some Leporinus species to the multiple sex chromosome system observed in L. elongatus. Considering the direct relationship between the LeSpeI element and sex chromosome differentiation, at least in L. elongatus, L. macrocephalus and L. obtusidens, the presence of LeSpeII in all of the anostomids studied here, including those without differentiated sex chromosomes (such as Leporinus friderici, L. striatus, L. lacustris, Schizodon borellii and S. isognathus), may represent an acquisition that is more ancient than that of the remaining repetitive elements already described in this family.

In the L. elongatus genome, the LeSpeII element is absent from the sex chromosomes $\left(\mathrm{W}_{1}, \mathrm{Z}_{2}\right.$ and $\left.\mathrm{W}_{2}\right)$, but it is widely distributed in the remaining autosomes. The absence of this element on $\mathrm{W}_{1}, \mathrm{Z}_{2}$ and $\mathrm{W}_{2}$ may have contributed to the fixing of the other repetitive elements. During another stage of differentiation, the accumulation of LeSpeI and LeSmaI sequences may have modified the accumulation of repetitive sequences in the L. elongatus genome [5,14], and a remarkable event such as a rearrangement may have promoted the formation of a multiple sex system in this species, since another heteromorphic pair $\left(Z_{2}\right.$ and $\left.W_{2}\right)$ was found only in this species [13].

In general, the acquisition of heterochromatin, which resulted in the development of a series of important characteristics unique to anostomids, is the most prominent route for chromosomal differentiation in this family [27-29]. Our results revealed amazing new characteristics of the Anostomidae genome and the results of the present study provide new insights into the pathways of chromosomal diversification of the species in this family and will be useful for future comparative genomic studies. The fishes, in general, comprise a basal group of vertebrates with a wide distribution of sex chromosome types that were brought about by events that resulted among others alterations, in changes in or multiplication of repetitive sequences. Therefore, this study also provides important insights into the evolution of the vertebrate genome.

\section{Materials and methods}

\section{Chromosomal and genomic DNA preparation}

Wild specimens of Leporinus elongatus (five males and eight females) were collected in the Mogi-Guaçú River, Pirassununga, São Paulo state, Brazil. Mitotic chromosome isolation and chromosome staining were performed according to Foresti et al. (1993) [30]. Additional cytogenetic studies were carried out with the species $L$. macrocephalus Garavello and Britiski 1988 (two males and two females), L. obtusidens (two males and two females), L. striatus Kner 1858 (one male and three females); L. lacustris Amaral Campos 1945 (one male and three females), L. friderici (Bloch 1794) (two males and three females), Schizodon borellii (Boulenger 1900) (two males and two females) and $S$. isognathus Kner 1858 (one male and one female), all of which were collected in the Paraguay River basin, Mato Grosso State, Brazil. Genomic DNA was extracted from liver and blood using standard methods [31]. The specimens were collected in accordance with collection license issued by Instituto Brasileiro do Meio Ambiente e dos Recursos Naturais Renováveis (19833-1), and the material was processed according to Colégio Brasileiro de Experimentação Animal (016/04 - CEEA).

The search for repetitive DNA was conducted using restriction enzyme digestions of genomic DNA of $L$. elongatus with different restriction endonucleases. The 

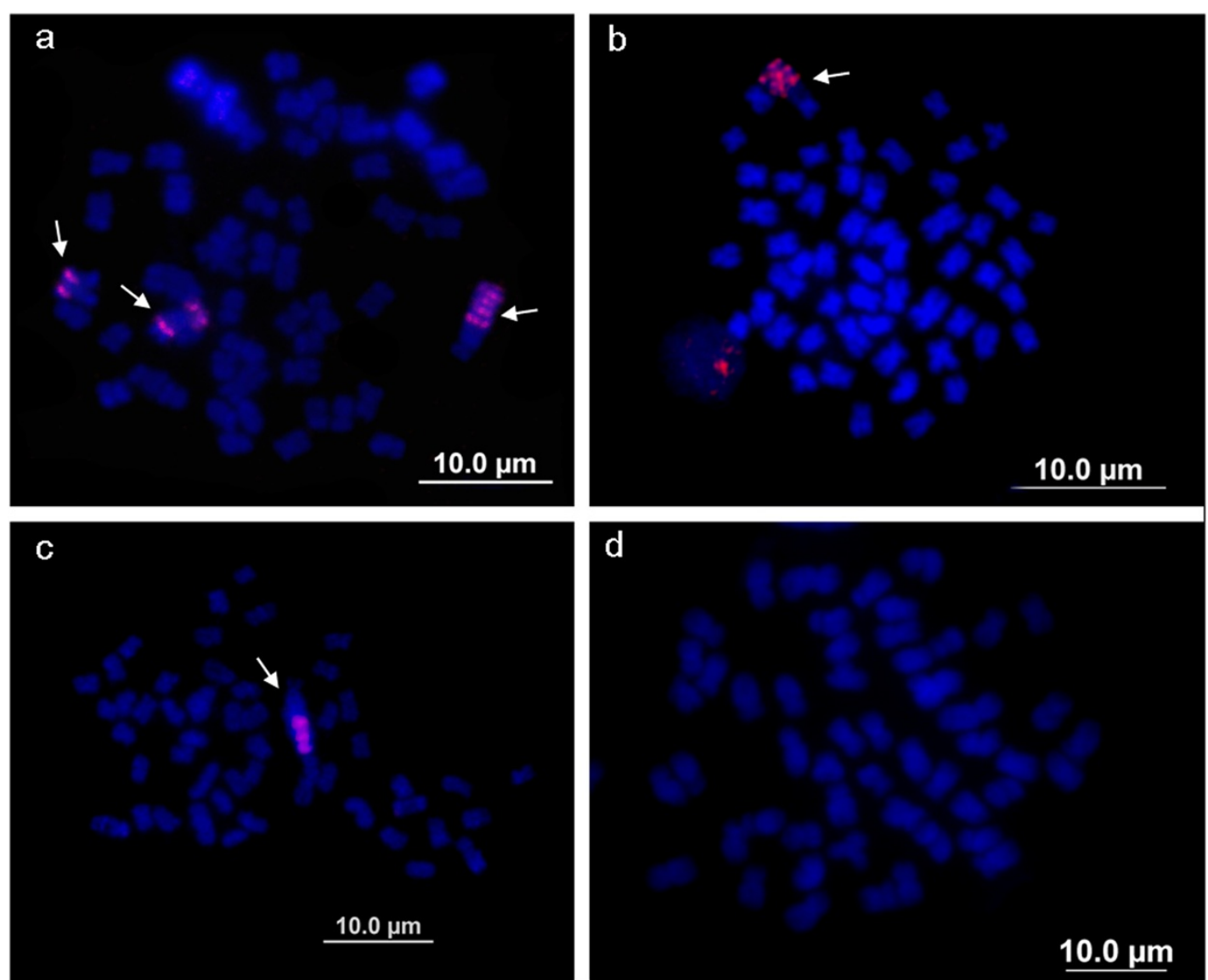

d
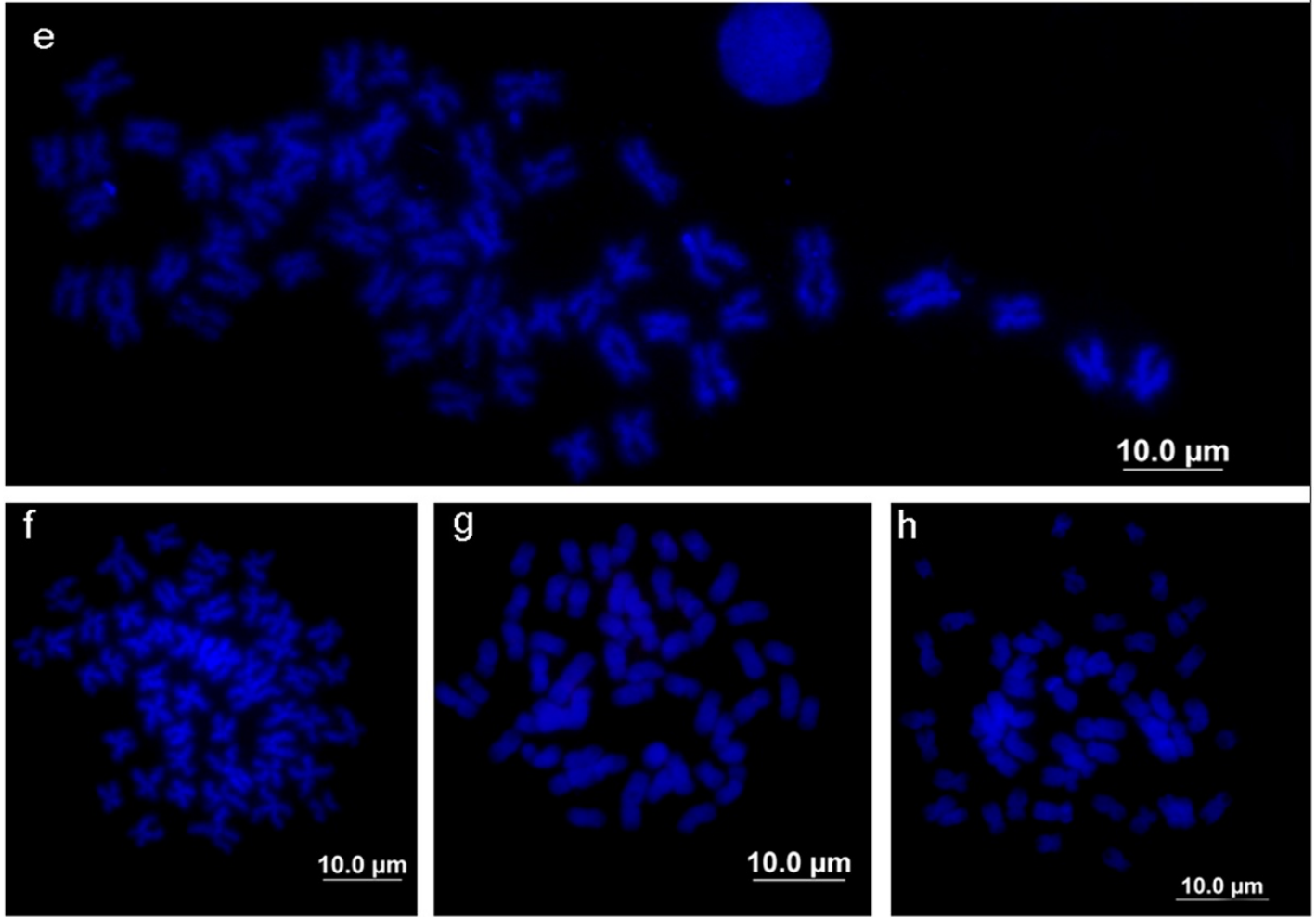

Figure 4 (See legend on next page.) 
(See figure on previous page.)

Figure 4 Mitotic metaphase chromosomes of female Anostomidae representatives hybridised with LeSpel repetitive element. a- Leporinus elongatus; b- L. macrocephalus; c- L. obtusidens; d- L. friderici; e- L. striatus; $\mathbf{f}-$ L. lacustris; $\mathbf{g}$ - Schizodon borellii; $\mathbf{h}-\mathrm{S}$ isognathus. Arrows indicate sex chromosomes in L. elongatus, L. macrocephalus and L. obtusidens.

endonuclease SpeI produced a conspicuous band of approximately $650 \mathrm{bp}$. This DNA band was isolated from a gel, cloned into the pMOS Blue plasmid vector (Amersham Biosciences), and used for transformation in E. coli DH5 $\alpha$ competent cells. Positive clones were identified and stored at $-75^{\circ} \mathrm{C}$ for future analysis.

\section{Sequencing and sequence analysis}

Two positives clones were isolated and sequenced using DYEnamic $^{\mathrm{TM}}$ ET Terminator Cycle Sequencing (Amersham Bioscience) and an ABI 377 automated DNA sequencer (Applied Biosystems). Nucleotide sequences were subjected to a search at the National Center for Biotechnology Information (NCBI) (http://www.ncbi.nlm.nih.gov/blast) [32], and sequence alignment was performed using Clustal W [33] and manually checked.

\section{Genomic organisation}

The genomic organisation of the isolated repetitive fragment was determined by Southern blot hybridisation with $10 \mu \mathrm{g}$ aliquots of genomic DNA from three L. elongatus males and three females. Genomic DNA was digested with the restriction enzyme Spel, and the restriction fragments were separated by electrophoresis in a $1.5 \%$ agarose gel and transferred onto a Hybond $\mathrm{N}+$ nylon membrane (Amersham Bioscience) by capillary action. Clones bearing the isolated repetitive fragment were used as probes and hybridised under high stringency conditions using an ECL Direct Nucleic Acid Labelling and Detection Systems Kit (Amersham Biosciences), according to the manufacturer's instructions.

\section{Chromosome mapping}

Chromosome mapping of repetitive sequences was performed using the isolated fragment and probes of the LeSpeI repetitive element [5] through FISH, according to the method of Pinkel et al. [34] with modifications described in Silva et al. (2012) [14]. The probes were labelled with digoxigenin in a second cycle of reamplification using the clone as the template for PCR with an M13 primer set (F 5'-TGT AAA ACG ACG GCC AGT-3'; R 5'-CAG GAA ACA GCT ATG ACC-3'). Hybridisation signals were detected using appropriate antibody sets composed of antidigoxigenin-rhodamine to detect the signals from the hapten digoxigenin.

Chromosomes were counterstained with DAPI mounted with antifade solution and observed using an Olympus BX51 microscope coupled to an Olympus digital camera (model D71). Chromosome images were captured using the DP Controller program.

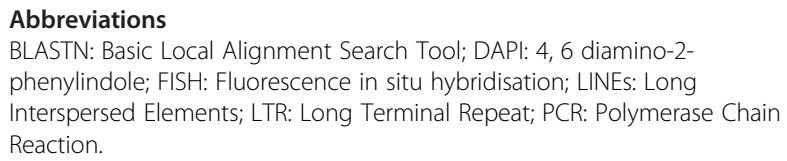

Competing interests

The authors declare that they have no competing interests.

\section{Authors' contributions}

ELS collected some of the animals, performed the cytogenetic studies and drafted the manuscript. RSB performed the cytogenetic studies and drafted the manuscript. PPPM collected some of the animals, supervised the cytogenetic studies, helped draft the manuscript and revised the final text. All authors read and approved the final manuscript.

\section{Acknowledgements}

The authors are grateful to Fundação de Amparo a Pesquisa do Estado de São Paulo (FAPESP) and Coordenação de Aperfeiçoamento de Pessoal de Nível Superior (CAPES) for financial support and Dr. Liano Centofante for help with field sampling and cytogenetic preparation.

Received: 11 September 2012 Accepted: 31 October 2012 Published: 11 December 2012

\section{References}

1. Oliveira C, Almeida-Toledo LF, Foresti F: Karyotypic evolution in Neotropical fishes. In Fish cytogenetics. Edited by Pisano E, Ozouf-Costaz C, Foresti F, Kappor BG. NH: Enfield; 2007:111-164. 2007.

2. Almeida-Toledo IF, Foresti F: Morphologically differentiated sex chromosomes in Neotropical freshwater fish. Genetica 2001, 111:91-100.

3. Devlin $\mathrm{RH}$, Nagahama Y: Sex determination and sex differentiation in fish: an overview of genetic, physiological, and environmental influences. Aquaculture 2002, 208:191-364.

4. Oliveira C, Foresti F, Hilsdorf AWS: Genetics of neotropical fish: from chromosomes to populations. Fish Physiol Biochem 2009, 35:81-100.

5. Parise-Maltempi PP, Martins C, Oliveira C, Foresti F: Identification of a new repetitive element in the sex chromosomes of Leporinus elongatus (Teleostei: Characiformes: Anostomidae): new insights into the sex chromosomes of Leporinus. Cytogenet Genome Res 2007, 116:218-223.

6. Cioffi MB, Bertollo LAC: Chromosomal distribution and evolution of repetitive DNAs fish. In Repetitive DNA. Edited by Garrido-Ramos MA. Basel: Karger; 2012:1-28. Genome Dyn. Vol. 7.

7. Cioffi MB, Kejnovsky E, Marquioni V, Poltronieri J, Molina W, Diniz D, Bertollo LAC: The key role of repeated DNAs in sex chromosome evolution in two fish species with ZW sex chromosome system. Mol Cytogenet 2012, 5:28. doi:10.1186/1755-8166-5-28.

8. Cioffi MB, Moreira-Filho O, Almeida-Toledo LF: The contrasting role of heterochromatin in the differentiation of sex chromosomes: an overview from Neotropical fishes. J Fish Biol 2012, 80:2125-2139.

9. López-Flores I, Garrido-Ramos MA: The Repetitive DNA Content of Eukaryotic Genomes. In Repetitive DNA. Edited by Garrido-Ramos MA. Basel, Karger: Genome Dyn; 2012:1-28. vol 7.

10. Charlesworth B, Snlegowski P, Stephan W: The evolutionary dynamics of repetitive DNA in eukaryotes. Nature 1994, 371:215-220.

11. Wagner RP, Maguire MP, Stallings RL: Chromosomes: a synthesis. New York: Wiley-Liss, Inc.; 1993.

12. Nakayama I, Foresti F, Tewari R, Schartl M, Chourrout D: Sex chromosome polymorphism and heterogametic males revealed by two cloned DNA probes in the ZW/ZZ fish Leporinus elongatus. Chromosoma 1994, 103:31-39. 
13. Marreta ME, Faldoni FLC, Parise-Maltempi PP: Cytogenetic mapping of the W chromosome in the genus Leporinus (Teleostei, Anostomidae) using a highly repetitive DNA sequence. J Fish Biol 2012, doi:10.1111/j.10958649.2011.03199.x.

14. Silva EL, Busso AF, Parise-Maltempi: Characterization and genome organization of a repetitive element associated with the nucleolar organizer region in Leporinus elongatus (Anostomidae: Characiformes). Cytogenet Genon Res 2012, doi:10.1159/000342957.

15. Koehler MR, Haaf T, Guttenbach M, Schartl M, Schmid T: Cytogenetics of the genus Leporinus (Pisces, Anostomidae). II. Molecular cytogenetics, organization and evolutionary conservation of a chromosome-specific satellite DNA from Leporinus obtusidens. Chrom Res 1997, 5:325-331.

16. Bernardi G: The human genome: organization and evolutionary history. Annu Rev Genet 1995, 29:445-476.

17. Oliveira C, Chew JSK, Porto-Foresti F, Dobson M, Wright JM: A LINE2 repetitive DNA sequence from the cichlid fish, Oreochromis niloticus: sequence analysis and chromosomal distribution. Chromosoma 1999, 108:457-468.

18. Higashiyama T, Noutoshi Y, Fujie M, Yamada T: Zepp a LINE like retrotransposon accumulated in the Chlorella telomeric region. EMBO J 1997, 16:3715-3723.

19. Gross MC, Schneider CH, Valente GT, Porto JIR, Martins C, Feldberg E: Comparative cytogenetic analysis of the genus Symphysodon (Discus fishes, Cichlidae): chromosomal characteristics of retrotransposons and minor ribosomal DNA. Cytogenet Genom Res 2009, 127:43-53.

20. Mazzuchelli J, Martins C: Genomic organization of repetitive DNAs in the cichlid fish Astronotus ocellatus. Genetica 2009, 136:461-469.

21. Ozouf-Costaz C, Brandt J, Korting C, Pisano E, Bonillo C, Coutanceau JP, Volff $\mathrm{JN}$ : Genome dynamics and chromosomal localization of the non-LTR retrotransposons Rex 1 and Rex3 in Antartic fish. Antartic Sci 2004, 16:51-57.

22. Kidwell MG: Transposable elements and the evolution of genome size in eukaryotes. Genetica 2002, 115:49-63.

23. Feschotte C, Pritham EJ: DNA transposons and the evolution of eukaryotic genomes. Annu Rev Genet 2007, 41:331-368.

24. Bohne A, Brunet F, Arnoux DG, Schultheis C, Volff JN: Transposable elements as drivers of genomic and biological diversity in vertebrates. Chrom Res 2008, 16:203-215.

25. Ohno S: Sex chromosomes and sex-linked genes. Berlin: Springer; 1967.

26. Ellegren H: Sex-chromosome evolution: recent progress and the influence of male and female heterogamety. Nat Rev Genet 2011, 12:157-166.

27. Galetti PM, Foresti F: Evolution of the ZZ/ZW system in Leporinus (Pisces, Anostomidae): the role of constitutive heterochromatin. Cytogenet Cell Genet 1986, 43:43-46.

28. Galetti PM, Mestriner CA, Venere PC, Foresti F: Heterochromatin and karyotype reorganization in fish of the family Anostomidae (Characiformes). Cytogenet Cell Genet 1991, 56:116-121.

29. Galetti PM, César ACG, Venere PC: Heterochromatin and NORs variability in Leporinus fish (Anostomidae, Characiformes). Caryologia 1991 44:287-292.

30. Foresti F, Oliveira C, Almeida-Toledo LFA: Method for chromosome preparations from large specimens of fishes using in vitro short treatment with colchicine. Experientia 1993, 49:810-813.

31. Sambrook J, Russel DW: Molecular cloning. A laboratory manual. Third editionth edition. New York: Cold Spring Harbor Laboratory Press; 2001.

32. Altschul SF, Madden TL, Schaffer AA, Zhang J, Zhang Z, Miller W, Lipman DJ: Gapped BLAST and PSI-BLAST: a new generation of protein database search programs. Nucleic Acids Res 1997, 25:3389-3402.

33. Thompson JD, Higgins DG, Gibson TJ: CLUSTAL W: improving the sensitivity of progressive multiple sequence alignment through sequence weighting, position-specific gap penalties and weight matrix choice. Nucl Acids Res 1994, 22:4673-4680

34. Pinkel D, Straume T, Gray JW: Cytogenetic analysis using quantitative, high-sensitivity, fluorescence hybridization. Proc Natl Acad Sci USA 1986, 83:2934-2938

doi:10.1186/1755-8166-5-45

Cite this article as: Silva et al:: Chromosome mapping of repetitive sequences in Anostomidae species: implications for genomic and sex chromosome evolution. Molecular Cytogenetics 2012 5:45.

\section{Submit your next manuscript to BioMed Central and take full advantage of:}

- Convenient online submission

- Thorough peer review

- No space constraints or color figure charges

- Immediate publication on acceptance

- Inclusion in PubMed, CAS, Scopus and Google Scholar

- Research which is freely available for redistribution

\section{Biomed Central}

